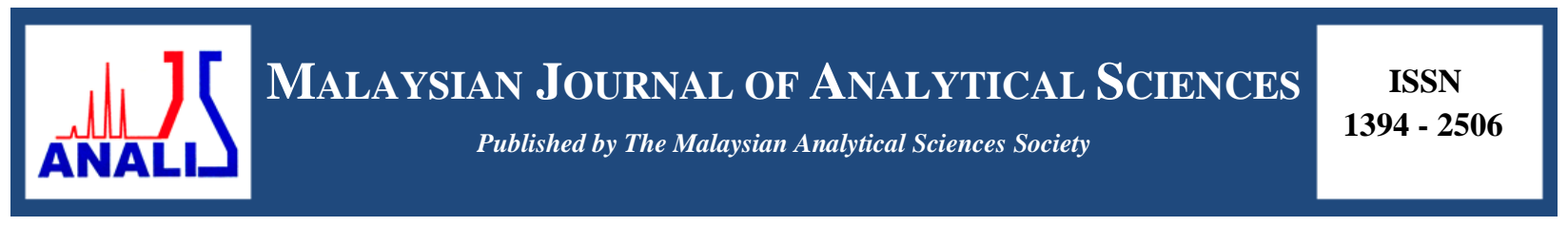

\title{
A FLUORESCENCE PHOSPHATE SENSOR BASED ON POLY(GLYCIDYL METHACRYLATE) MICROSPHERES WITH ALUMINIUM-MORIN
}

\author{
(Sensor Fosfat Berpendarfluor Berasaskan Mikrosfera Poli(Glisidil Metakrilat) dengan \\ Aluminium-Morin) \\ Amalina Ahmad ${ }^{1}$, Norhadisah Mohd Zaini ${ }^{1}$, Normazida Rozi ${ }^{1}$, Nurul Huda Abd Karim ${ }^{1}$, Siti Aishah Hasbullah ${ }^{1}$, \\ Lee Yook Heng ${ }^{1}$, Sharina Abu Hanifah ${ }^{1,2 *}$ \\ ${ }^{I}$ School of Chemical Sciences and Food Technology \\ ${ }^{2}$ Center for Water Research and Analysis \\ Faculty of Science and Technology, \\ Universiti Kebangsaan Malaysia, 43600 UKM Bangi, Selangor, Malaysia \\ *Corresponding author: sharina@ukm.edu.my
}

Received: 8 December 2015; Accepted: 11 March 2016

\begin{abstract}
The performance of new phosphate sensor was investigated using fluorescence spectrometer in the form of immobilized Almorin on poly(glycidyl methacrylate) (pGMA) microspheres. pGMA microspheres that were synthesized by using suspension photopolymerization exhibited spherical-shaped morphology with diameters from 1.5 to $5.3 \mu \mathrm{m}$. The studies were carried out at $\mathrm{pH} 5$ and the ratio of aluminium (III) chloride hexahydrate to morin was $3: 1(\mathrm{v} / \mathrm{v})$. At $\mathrm{pH} 5, \mathrm{H}_{2} \mathrm{PO}_{4}{ }^{-}$was measured at $548 \mathrm{~nm}$ emission wavelength. The relative fluorescence intensity was inversely proportional to $\mathrm{H}_{2} \mathrm{PO}_{4}{ }^{-}$concentrations. The linear range was observed between $6.6-58.8 \mu \mathrm{mol} / \mathrm{L}$ with detection limit (LOD) of $0.7 \mu \mathrm{mol} / \mathrm{L}$. Ion interference study demonstrated that $\mathrm{Al}-$ morin was highly selective towards $\mathrm{H}_{2} \mathrm{PO}_{4}{ }^{-}$.
\end{abstract}

Keywords: phosphate sensor, polymer microspheres, aluminium-morin, fluorescence

\begin{abstract}
Abstrak
Prestasi sensor fosfat baru telah dikaji dengan menggunakan spektrometer pendarfluor dalam bentuk Al-morin terpegun pada mikrosfera poli(glisidil metakrilat) (pGMA). Mikrosfera pGMA yang disintesis dengan menggunakan pemfotopolimeran ampaian mempamerkan morfologi berbentuk sfera dengan diameter 1.5 hingga $5.3 \mu \mathrm{m}$. Kajian telah dijalankan pada $\mathrm{pH} 5$ dan nisbah aluminium (III) klorida heksahidrat kepada morin adalah 3: 1 (v/v). Pada $\mathrm{pH} 5, \mathrm{H}_{2} \mathrm{PO}_{4}{ }^{-}$diukur pada gelombang pancaran $548 \mathrm{~nm}$. Keamatan pendarfluor relatif adalah berkadar songsang dengan kepekatan $\mathrm{H}_{2} \mathrm{PO}_{4-}$ Julat linear diperhatikan antara $6.6-$ $58.8 \mu \mathrm{mol} / \mathrm{L}$ dengan had pengesanan (LOD) pada $0.7 \mu \mathrm{mol} / \mathrm{L}$. Kajian gangguan ion menunjukkan Al-morin adalah sangat selektif kepada $\mathrm{H}_{2} \mathrm{PO}_{4}^{-}$.
\end{abstract}

Kata kunci: sensor fosfat, polimer mikrosfrera, aluminium-morin, pendafluor

\section{Introduction}

Phosphorus can be divided into organic phosphate and inorganic phosphate. Phosphate ions that move freely in water known as orthophosphate $\left(\mathrm{P}_{\mathrm{i}}\right)$ which is an inorganic phosphate [1]. High phosphate content in water can cause eutrophication. Eutrophication is the excess nutrients in aquatic ecosystems that bring to an excess algae growth and cause water and environmental problem [2]. Thus, monitoring phosphate in drinking water is vital to ensure that water quality follows the standard. The maximum concentration of phosphate recommended by World Health 
Organization (WHO) is $1 \mathrm{mgL}^{-1}[3]$. Besides, the determination of phosphate concentrations in body fluids is necessary to diagnose hyperparathyroidism, hypertension [4], vitamin D deficiency, mineral and bone disorder, kidney failure [5] and Franconia syndrome [6,7].

Optical sensor is a device that converts light rays into electronic signals [8]. Fluorescence, luminescence, chemiluminescence and UV-visible spectrophotometers are commonly applied instruments in optical sensors [3]. Fluorescence method is widely used because it is highly sensitive, easy to operate, response rapidly and less costly [9]. Phosphate has known to quench aluminium-morin (Al-morin) fluorescence intensity. During 1950's, Al-morin has been used to detect trace amount of fluoride ion and indirectly phosphate was determined to be an interfering ion [10]. Previously, Hong et al. [11] reported that Al-morin immobilized on PVA/PVC plasticized composite membrane based on sandwich configuration has been used in phosphate detection. This technique had improved the indicator leaching problem however produced narrow linear range of phosphate detection $(11.0-51.4 \mu \mathrm{mol} / \mathrm{L})$. In order to overcome its limitation, Lin et al. [12] claimed that Al-morin immobilized on pretreated PVC membrane is more sensitive as it produces wider linear range $(44.1-110.2 \mu \mathrm{mol} / \mathrm{L})$.

In this work, phosphate sensor was developed by immobilizing Al-morin onto poly(glycidyl methacrylate) (pGMA) microspheres which were synthesized by suspension photopolymerization technique. High surface area of pGMA microspheres is suitable for Al-morin immobilization matrix in order to increase the reaction site for phosphate detection. The microspheres are also a water-insoluble polymer, causing it to be applicable in phosphate sensing. All characterizations of immobilized Al-morin phosphate sensors were analyzed by fluorimetric method.

\section{Apparatus and reagent}

\section{Materials and Methods}

Chemicals including morin hydrate (98\%, MP Biomedicals LLC), aluminium (III) chloride hexahydrate $\left(\mathrm{AlCl}_{3} .6 \mathrm{H}_{2} \mathrm{O}\right)(99 \%$, Systerm), glycidyl methacrylate (97\%, Sigma Aldrich), ethylene glycol dimethacrylate (9 8\%, Sigma Aldrich), polyvinyl alcohol (98\%, Sigma Aldrich), 2,2-dimethoxy-2-phenylacetophenone (99\%, Sigma Aldrich), potassium dihydrogen phosphate ( $99 \%$, Systerm), potassium carbonate $\left(\mathrm{K}_{2} \mathrm{CO}_{3}\right)(99 \%$, Sigma Aldrich), potassium acetate $\left(\mathrm{CH}_{3} \mathrm{COOK}\right)(99 \%$, Sigma Aldrich), potassium chloride $(\mathrm{KCl})(99 \%$, Sigma Aldrich), potassium fluoride (KF) (99\%, Sigma Aldrich), potassium nitrate $\left(\mathrm{KNO}_{3}\right)(99 \%$, BDH Chemicals Ltd), potassium sulfate $\left(\mathrm{K}_{2} \mathrm{SO}_{4}\right)(99 \%$, Sigma Aldrich) and ethanol (95\%, Sigma Aldrich) were used as received.

The surface of microspheres was observed using Zeiss LEO 1450VP Scanning Electron Microscope (SEM). Infrared spectra of the microspheres were recorded by Fourier Transform Infrared spectrometer (Perkin Elmer) using attenuated total reflection (ATR-FTIR) spectrometry method. Response of Al-morin complex on fluorescence intensity was measured by Perkin Elmer Fluorescence Spectrometer at $548 \mathrm{~nm}$ emission wavelength.

\section{Synthesis of Al-morin complex}

A concentration of $23.2 \mu \mathrm{mol} / \mathrm{L}$ Morin solution was prepared in ethanol and $16.6 \mu \mathrm{mol} / \mathrm{L}$ aluminium (III) chloride hexahydrate $\left(\mathrm{AlCl}_{3} \cdot 6 \mathrm{H}_{2} \mathrm{O}\right)$ in deionized water. Al-morin complex was formed by mixing $\mathrm{AlCl}_{3} \cdot 6 \mathrm{H}_{2} \mathrm{O}$ with Morin in 3:1 ( $\mathrm{v} / \mathrm{v})$. The formation of Al-morin was then confirmed when the fluorescence emission of Al-morin was determined to be at wavelength $510 \mathrm{~nm}$ as reported in the literature [12].

\section{Synthesis of poly(glycidyl methacrylate) (pGMA) microspheres}

An mount of $1 \mathrm{ml}$ of glycidyl methacrylate (GMA), $1 \mathrm{ml}$ of ethylene glycol dimethacrylate (EGDMA), $5 \mathrm{ml}$ of $1 \%$ polyvinyl alcohol (PVA) and $1.6 \%(\mathrm{w} / \mathrm{w})$ of 2,2-dimethoxy-2-phenylacetophenone (DMPP) were placed in a vial. The mixture was sonicated within 15 minutes. The suspension was transferred into a petri dish and photocured under continuous nitrogen flow for 10 minutes. The microspheres were collected by centrifugation at $2000 \mathrm{rpm}$ for 10 minutes. They were then left to dry at room temperature. pGMA microspheres were characterized by Scanning Electron Microscope (SEM) and Attenuated Total Reflectance-Fourier-transform Infrared (ATR-FTIR) spectrometer. 


\section{Immobilization of Al-morin onto pGMA microspheres}

An amount of $20-30 \%(\mathrm{v} / \mathrm{v})$ of Aluminium-Morin (Al-morin) complex was added into the mixture of GMA monomer, $1 \mathrm{ml}$ ethylene glycol dimethylacrylate (EGDMA), $5 \mathrm{ml}$ of $1 \%$ polyvinyl alcohol (PVA) and 1.6\% (w/w) of 2,2-dimethoxy-2-phenylacetophenone (DMPP) in a vial. The mixture was sonicated within 15 minutes then it was transferred into a petri dish for photocuring procedure under continuous nitrogen flow for 10 minutes. The microspheres were collected by centrifugation at $2000 \mathrm{rpm}$ for 10 minutes and dried at room temperature. pGMA/Al-morin microspheres were characterized by SEM and ATR-FTIR.

\section{pH analysis}

The optimum $\mathrm{pH}$ for $\mathrm{Al}$-morin to react with $110.2 \mu \mathrm{mol} / \mathrm{L}$ dihydrogen phosphate $\left(\mathrm{H}_{2} \mathrm{PO}_{4}{ }^{-}\right)$was studied. pGMA/Almorin microspheres were soaked in $\mathrm{pH} 1$ buffer solution before they were next soaked into phosphate solution prepared at $\mathrm{pH} 1$ for 5 minutes as reported previously [13]. These steps were repeated for analyzing the same concentration of phoshate solution at $\mathrm{pHs}$ ranging from 1 to 7 . Fluorescence intensity before and after Al-morin reacts with phosphate were recorded by calculating the relative of fluorescence intensity at $548 \mathrm{~nm}$.

\section{Effect of phosphate concentration}

pGMA/Al-morin microspheres were soaked in dihydrogen phosphate $\left(\mathrm{H}_{2} \mathrm{PO}_{4}{ }^{-}\right)$solution prepared at pH 5 buffer with concentrations ranging from $0.7-124.9 \mu \mathrm{mol} / \mathrm{L}$ for 5 minutes. They were initially soaked at $\mathrm{pH} 5$ buffer to remove the unreacted monomer. The fluorescence intensity of immobilized Al-morin before and after reacting with phosphate for each concentration was measured at $548 \mathrm{~nm}$.

\section{Effect of interference ions}

Interference study was carried out by preparing a fixed concentration of $\mathrm{H}_{2} \mathrm{PO}_{4}{ }^{-}(110.2 \mu \mathrm{mol} / \mathrm{L})$ in the presence of common anions including carbonate $\left(\mathrm{CO}_{3}{ }^{2-}\right)$, acetate $\left(\mathrm{CH}_{3} \mathrm{COO}^{-}\right)$, chloride $\left(\mathrm{Cl}^{-}\right)$, fluoride $\left(\mathrm{F}^{-}\right)$, nitrate $\left(\mathrm{NO}_{3}^{-}\right)$and sulfate $\left(\mathrm{SO}_{4}{ }^{2-}\right)$. Each anion at the same concentration as $\mathrm{H}_{2} \mathrm{PO}_{4}^{-}$was prepared. Fluorescence intensity of pGMA/Almorin microspheres soaked in the analyte containing $\mathrm{H}_{2} \mathrm{PO}_{4}{ }_{4}^{-}$and interference ions were recorded at $548 \mathrm{~nm}$.

\section{Characterization of Al-morin immobilized onto pGMA}

\section{Results and Discussion}

\section{Morphology of pGMA microspheres}

pGMA microspheres were used as a matrix to immobilize Al-morin complex. High surface area of these microspheres makes it possible to act as a matrix with good physical properties and these microspheres are chemically stable. pGMA microspheres were prepared using a rapid synthesis method, which is suspension photopolymerization. The droplets of monomer mixtures form pGMA at room temperature in the presence of DMPP. The polymerization process was terminated by the removal of the ultraviolet (UV) light source. The schematic polymerization of GMA is presented in Figure 1.

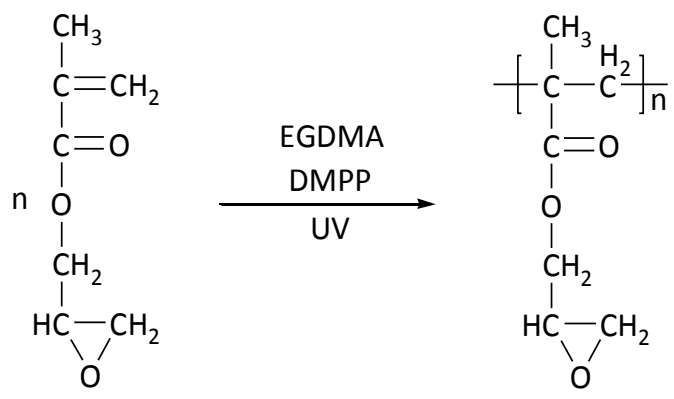

glycidyl methacrylate

(GMA) poly(glycidyl methacrylate)

(pGMA)

Figure 1. Polymerization of GMA microspheres 
The spheres produced by this approach varied in size from 1.5 to $5.3 \mu \mathrm{m}$ and are polydisperse. The size maintains even after Al-morin was immobilized onto pGMA microspheres. This observation might be due to the entrapment of chemical doping technique used to immobilize Al-morin which did not involve any chemical bonding. The presence of $\mathrm{Al}$-morin causes pGMA/Al-morin microspheres to exhibit rougher surface compared to pGMA. The roughness of the microspheres surface has provides higher surface area [14]. SEM micrographs of pGMA microspheres and pGMA/Al-morin are presented in Figure 2.
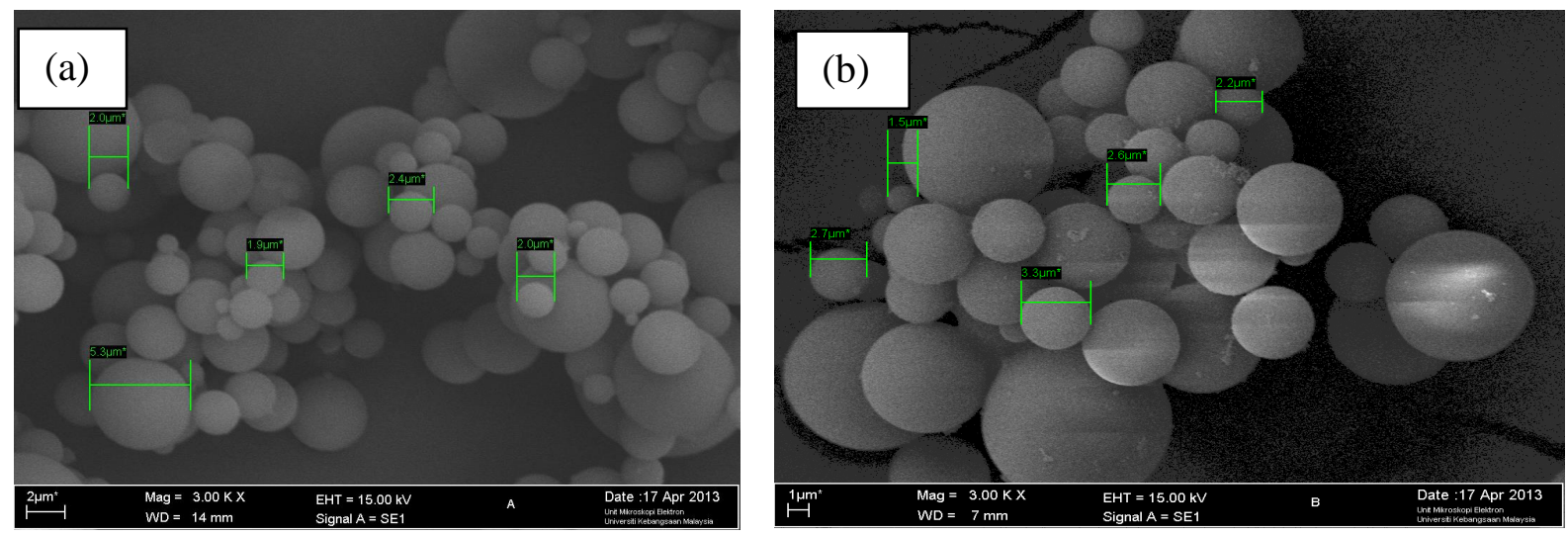

Figure 2. Surface morphology of microspheres (A) pGMA and (B) pGMA with Al-morin

Spherical matrix is capable to maximize the surface area of sensor reagent and reduce the response time by allowing the analyte to penetrate through the matrix [15]. This shows that pGMA provides high surface area for phosphate detection and increases the chemisensor sensitivity. Microspheres optical chemisensor can reduce sample volume, increase sensitivity, shorten response time and reduce detection limit [16].

\section{ATR-FTIR spectra of pGMA/Al-morin}

ATR-FTIR spectra of pGMA and pGMA/Al-morin microspheres are shown in Figure 3. Both types of pGMA spectra have recorded a strong band at $1721 \mathrm{~cm}^{-1}$ (pGMA) and $1722 \mathrm{~cm}^{-1}$ (pGMA/Al-morin) due to $\mathrm{C}=\mathrm{O}$ vibrations. Furthermore, bands of $843 \mathrm{~cm}^{-1}$ and $905 \mathrm{~cm}^{-1}$ correspond to the epoxy groups. No additional peak can be seen between pGMA and pGMA/Al-morin bands. This result confirms that the pGMA and Al-morin involved entrapment method which does not involve any chemical bonding between Al-morin complex and the GMA polymer.

\section{Optimization of pGMA/Al-morin pH analysis}

Figures 4 shows graph of fluorescence intensity versus $\mathrm{pH}$ that was measured at $548 \mathrm{~nm}$ respectively. $\mathrm{pH} 5$ was determined to be the optimum $\mathrm{pH}$ for pGMA/Al-morin to react with $\mathrm{H}_{2} \mathrm{PO}_{4}^{-}$. Mohr and Wolfbeis [17] have reported that $\mathrm{H}_{2} \mathrm{PO}_{4}{ }^{-}$is the predominant form of phosphate at $\mathrm{pH} 5$. At $\mathrm{pH}<5$, low fluorescence intensity could be related to the protonation of $\mathrm{H}_{2} \mathrm{PO}_{4}{ }^{-}$to form $\mathrm{H}_{3} \mathrm{PO}_{4}$ resulting in a poor ability of $\mathrm{H}_{2} \mathrm{PO}_{4}{ }^{-}$to interact with Al-morin. Furthermore at $\mathrm{pH}>5$, gradual decrease in fluorescence intensity is observed which may be due to hydroxide ions interference and formation of other form of phosphate ions [18].

\section{Effect of phosphate concentrations}

Morin ( $2^{\prime}, 3,4^{\prime}, 5,7$-pentahydroxyflavone) is brown in colour when dissolves in ethanol and turn to light yellow solution as it is diluted. Free morin is weakly fluorescent and it becomes stronger as it forms a complexe with aluminium [19]. However, the fluorescence of Al-morin complex quenches distinctly when phosphate is introduced into the system [12]. The proposed reaction between Al-morin with $\mathrm{H}_{2} \mathrm{PO}_{4}{ }^{-}$is shown in Figure 5. 


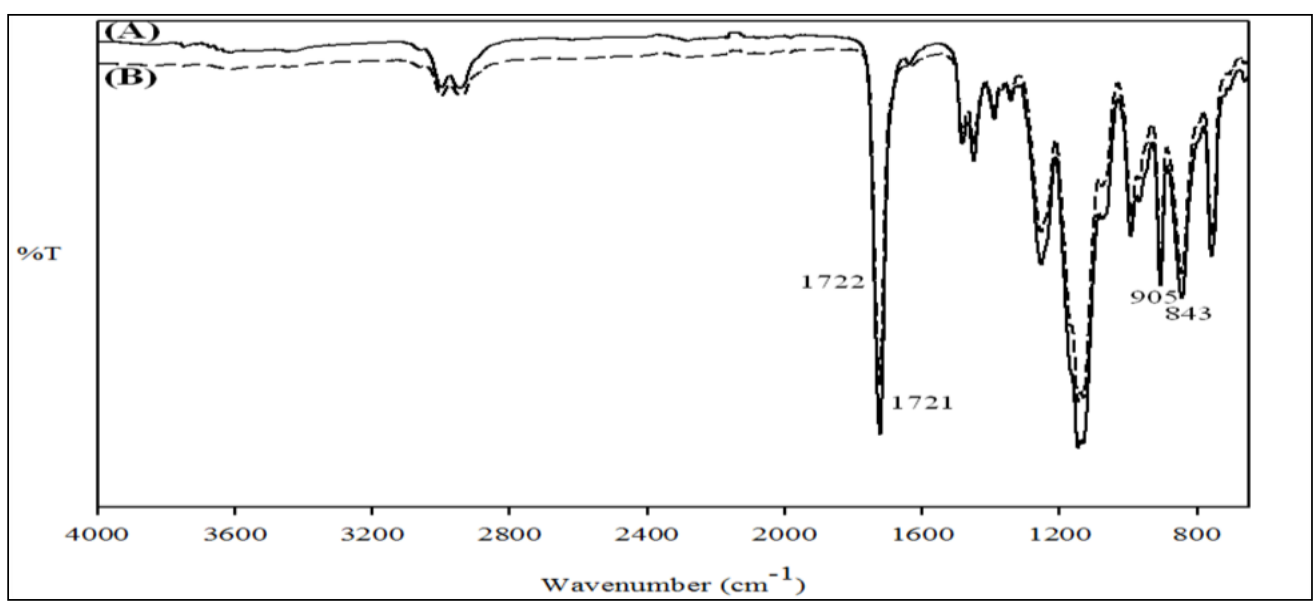

Figure 3. ATR-FTIR spectra of (A) pGMA and (B) pGMA/Al-morin microspheres

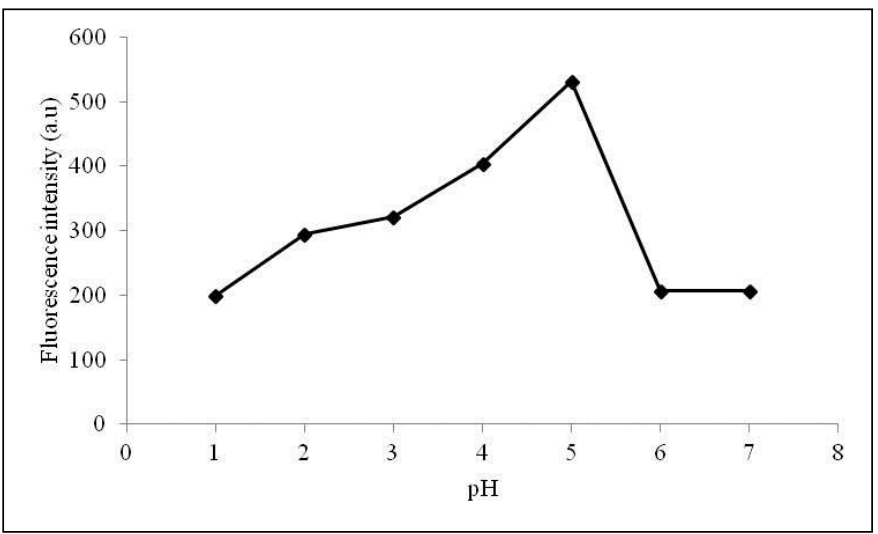

Figure 4. Effect of $\mathrm{pH}$ on pGMA/Al-morin with $\mathrm{H}_{2} \mathrm{PO}_{4}{ }^{-}$

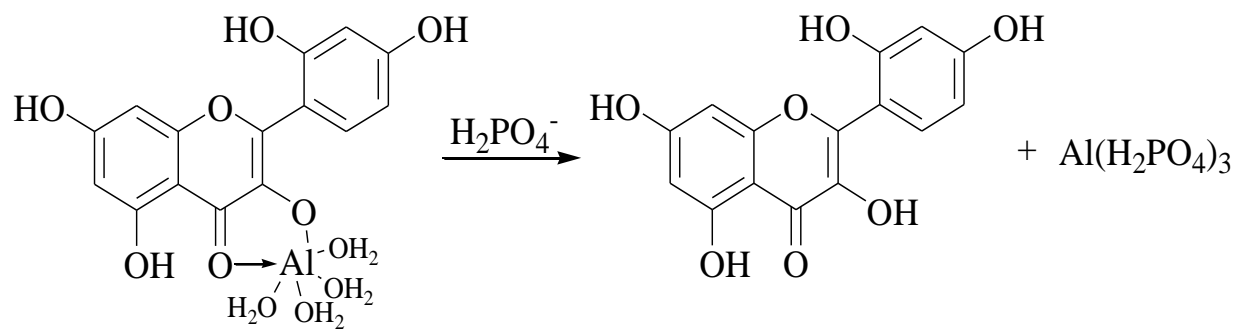

Al-morin (strong fluorescence)

Morin (weak fluorescence) Al(III)-dihydrogenphosphate

Figure 5. Proposed chemical reaction of Al-morin with phosphate anion.

Study on the effect of phosphate concentration was carried out at $\mathrm{pH} 5$ to investigate the ability of immobilized Almorin in detecting $\mathrm{H}_{2} \mathrm{PO}_{4}{ }^{-}$at various concentrations. The pGMA/Al-morin microspheres was allowed to react with 
$\mathrm{H}_{2} \mathrm{PO}_{4}{ }^{-}$at a fixed concentration within 5 minutes before analyzing by fluorescence spectrometer. Figure 6 shows the fluorescence intensity of pGMA/Al-morin reached equilibrium at $124.9 \mu \mathrm{mol} / \mathrm{L} \mathrm{H}_{2} \mathrm{PO}_{4}{ }^{-}$with the linearity from 6.6 to $58.8 \mu \mathrm{mol} / \mathrm{L}$ (inset) and a detection limit as low as $0.7 \mu \mathrm{mol} / \mathrm{L}$. This sensor produced higher range of phosphate concentration compared to poly(vinyl chloride) and poly(vinyl alcohol) based membrane may be due to larger surface area provided by pGMA microspheres $[11,12,20]$.

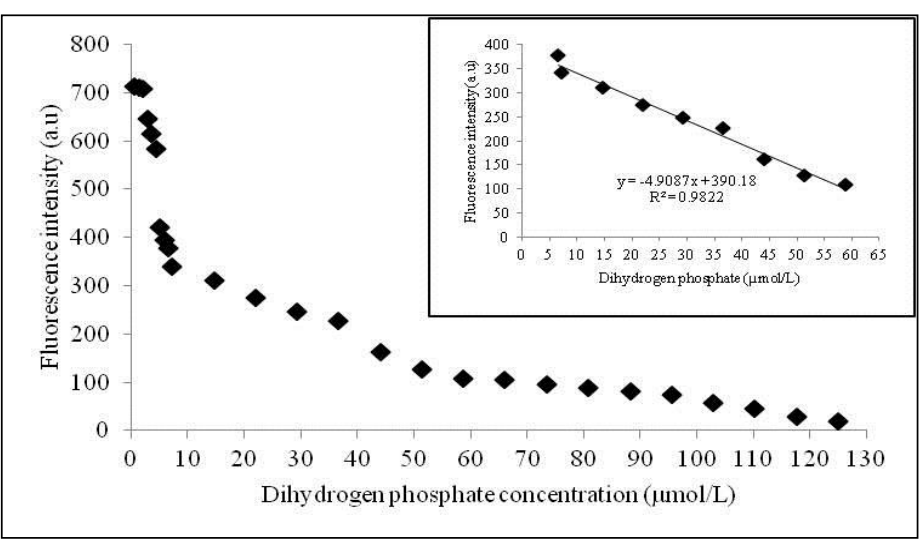

Figure 6. Calibration curve and linear range (inset) of pGMA/Al-morin based sensor towards different phosphate concentrations at $\mathrm{pH} 5$.

PET mechanism

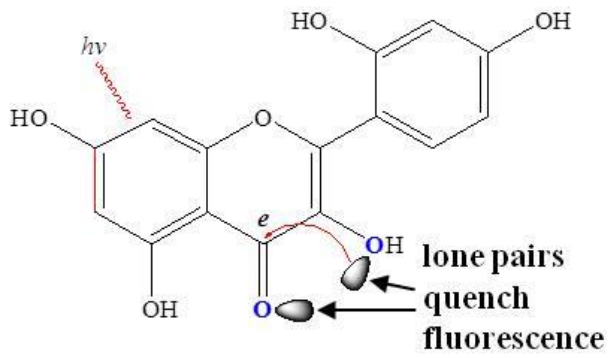

Free ligand

\section{CHEF effect restores fluorescence}<smiles></smiles>

Figure 7. PET and CHEF effects on morin complexation.

The relative fluorescence intensity is inversely proportional to $\mathrm{H}_{2} \mathrm{PO}_{4}^{-}$concentrations. The quenching of fluorescence could be further explained in Figure 7 [21]. It is possibly an example of CHEF (Chelation-Enhanced Fluorescence) and PET (Photoinduced Electron Transfer) phenomenons. CHEF effect is related to the photoinduced electron transfer (PET) mechanism. In the PET mechanism, exciting radiation induces electrons in the free ligand to transfer from the lone pairs on donor atoms (O-donors) to the $\pi$-system of the fluorophores and resulting in fluorescence quenching. These same lone pairs which involve in bonds formation with metal ions reduce the PET quenching effect. This occurrence leads to the CHEF effect, where metal ions can be detected by the increment of fluorescence intensity [22]. In this case, introducing $\mathrm{H}_{2} \mathrm{PO}_{4}{ }^{-}$to the system reduces the fluorescence intensity as aluminium detaches from morin by forming aluminium dihydrogenphosphate, $\mathrm{Al}\left(\mathrm{H}_{2} \mathrm{PO}_{4}\right)_{3}$. This is due to poor fluorescence of non-chelating morin. Simultaneously, PET involves explaining about this phenomenon. Lone pairs 
on morin O-donor atoms are no longer chelated with metal ion thus leading to increase PET quenching effect and indirectly reduce the fluorescence intensity.

\section{Effect of Ions Interference}

According to Table 1, pGMA/Al-morin was highly selective for $\mathrm{H}_{2} \mathrm{PO}_{4}{ }^{-}$over other anions which were commonly present in water samples such as $\mathrm{CO}_{3}{ }^{2-}, \mathrm{CH}_{3} \mathrm{COO}^{-}, \mathrm{Cl}^{-}, \mathrm{F}^{-}, \mathrm{NO}_{3}{ }^{-}$and $\mathrm{SO}_{4}{ }^{2-}$. The higher affinity for $\mathrm{H}_{2} \mathrm{PO}_{4}{ }^{-}$over other anions may be caused by the presence of appropriately spaced cationic charges, $\mathrm{Al}^{3+}$ [23]. All the interfering ions do not affect much on the detection of $\mathrm{H}_{2} \mathrm{PO}_{4}{ }^{-}$because the percentage of interference was less than $10 \%$ [24-26].

Table 1. Percentage of ion interference of immobilized Al-morin at $\mathrm{pH} 5$.

\begin{tabular}{lc}
\hline Ion interference & Percentage of interference (\%) \\
\hline Carbonate, $\mathrm{CO}_{3}{ }^{2-}$ & 1.51 \\
Acetate, $\mathrm{CH}_{3} \mathrm{COO}^{-}$ & 0.52 \\
Chloride, $\mathrm{Cl}^{-}$ & 5.43 \\
Floride, $\mathrm{F}^{-}$ & 0.00 \\
Nitrate, $\mathrm{NO}_{3}{ }^{-}$ & 2.74 \\
Sulfate, $\mathrm{SO}_{4}{ }^{2-}$ & 1.58 \\
\hline
\end{tabular}

Performance of pGMA microspheres in the present study and PVC based membranes for immobilizing Al-morin is summarized in Table 2. It is clearly seen that pGMA/Al-morin has improved phosphate sensor performance compared to polyvinyl alcohol/ polyvinyl chloride/ aluminium-morin (PVA/PVC/Al-morin) composite membrane [11] and PVC/Al-morin matrix membrane [12] for $\mathrm{H}_{2} \mathrm{PO}_{4}{ }^{-}$detection. pGMA/Al-morin microspheres serves as a useful matrix for rapid phosphate measurement as the response time was recorded within 5 minutes.

Table 2. Summary of Al-morin phosphate sensor performances.

\begin{tabular}{lccc}
\hline Parameters & $\begin{array}{c}\text { pGMA/Al-morin } \\
\text { micropsheres }\end{array}$ & $\begin{array}{c}\text { PVA/PVC/Al-morin } \\
\text { membrane }^{\mathbf{a}}\end{array}$ & $\begin{array}{c}\text { PVC/Al-morin } \\
\text { membrane }^{\mathbf{b}}\end{array}$ \\
\hline $\mathrm{pH}$ & 5 & 4 & 5 \\
$\begin{array}{l}\text { Dynamic range } \\
(\mu \mathrm{mol} / \mathrm{L})\end{array}$ & $0.7-124.9$ & $3.7-73.5$ & $7.3-132.3$ \\
$\begin{array}{l}\text { Linear range } \\
(\mu \mathrm{mol} / \mathrm{L})\end{array}$ & $6.6-58.8$ & $11.0-51.4$ & $44.1-110.2$ \\
$\begin{array}{l}\text { Limit of detection } \\
(\mu \mathrm{mol} / \mathrm{L})\end{array}$ & 0.7 & 0.1 & 0.1 \\
\hline${ }^{\mathrm{a}}[11]^{\mathrm{b}}[12]$ & & &
\end{tabular}

\section{Conclusion}

A convenient method for preparing pGMA/Al-morin microspheres for the development of optical phosphate sensor has been highlighted. pGMA/Al-morin microspheres have the ability to detect phosphate within a short time, high selectivity and able to measure phosphate concentrations at wider linear range caused by high surface area of the microspheres. 


\section{Acknowledgement}

The authors would like to extend their gratitude towards Universiti Kebangsaan Malaysia for providing research facilities that was used in this research. This work was supported by the UKM grants DPP-2015-064 and ICONIC2013-004.

\section{References}

1. Kramer, M. (2008). Protein engineering of pyruvate oxidase from Lactobacillus plantarum for application in biosensors. Thesis Diss. Naturwissenschaften, Eidgenössische Technische Hochschule ETH Zürich, Nr. 17765.

2. Carpenter, S. R. (2005). Eutrophication of aquatic ecosystems: biostability and soil phosphorus. Proceedings of the National Academy of Sciences of the United States of America, 102(29): 10002 - 10005.

3. Lawal, A. T. and Adeloju, S. B. (2013). Progress and recent advances in phosphate sensors: A review. Talanta, 114: $191-203$.

4. Kumar, R. (2009). Phosphate sensing. Current Opinion in Nephrology and Hypertension, 18(4): 281 - 284.

5. Slatopolsky, E. (2011). The intact nephron hypothesis: the concept and its implications for phosphate management in CKD-related mineral and bone disorder. Kidney International, 79: 3 - 8 .

6. Engblom, S. O. (1998). The phosphate sensor. Biosensors and Bioelectronics, 13(9): 981 - 994.

7. Kawasaki, H., Sato, K., Ogawa, J., Hasegawa, Y. and Yuki, H. (1989). Determination of inorganic phosphate by flow injection method with immobilized enzymes and chemiluminescence detection. Analytical Biochemistry, 182(2): $366-370$.

8. Ahuja, D. and Parande, D. (2012). Optical sensors and their applications. Journal of Scientific Research and Reviews, 1(5): $60-68$.

9. Noh, J. Y., Hwang, I. H., Kim, H., Song, E. J., Kim, K. B. and Kim, C. (2013). Salicylimine-based colorimetric and fluorescent chemosensor for selective detection of cyanide in aqueous buffer. Bulletin Korean Chemical Society, 34(7): 1985 - 1989.

10. Willard, H. H. and Horton, C. A. (1952). Fluorometric determinations of traces of fluoride. Analytical Chemistry, 24(5): $862-865$.

11. Xie, Z. H., Lin, X. C. and Chen, G. N. (2003). Novel phosphate-sensitive fluorescent composite matrix. Chemical Research Chinese Universities, 19(2): 201 - 205.

12. Lin, X., Wu, X., Xie, Z. and Wong, K. Y. (2006). PVC matrix membrane sensor for fluorescent determination of phosphate. Talanta, 70(1): $32-36$.

13. Ahmad, A., Hanifah, S. A., Hasbullah, S. A., Suhud, K., Zaini, N. M. and Heng, L. Y. (2014). Phosphate sensor based on immobilized aluminium-morin in poly(glycidyl methacrylate) microspheres. AIP Conference Proceedings, 1614(1): 486 - 491.

14. Denizli, A., Garipcan, B., Karabakan, A. and Senoz, H. 2005. Synthesis and characterization of poly(hyroxyethyl methacrylate- $N$-methacryloyl-(L)-glumatic acid) copolymer beads for removal of leads ions. Materials Sciences and Engineering Journal C, 25(4): 448 - 454.

15. Peper, S., Tsagkatakis, I. and Bakker, E. 2001. Cross-linked dodecyl acrylate microspheres: novel matrices for plasticizer-free optical ion sensing. Analytica Chimica Acta 442(1): 25 - 33.

16. Xu, C., Wygladacz, K., Qin, Y., Retter, R., Bell, M. and Bakker, E. 2005. Microsphere optical ion sensors based on doped silica gel templates. Analytica Chimica Acta 537(1): 135 - 143.

17. Mohr, G. J. and Wolfbeis, O. S. 1995. Optical sensing of anions via polarity-sensitive dyes: a bulk sensor membrane for nitrate. Analytica Chimica Acta 316(1995) 239 - 246.

18. Chandra, S., Raizada S. and Sharma, S. 2012. Highly selective monohydrogen phosphate anion sensor for $[\mathrm{CrL}]\left(\mathrm{NO}_{3}\right)_{3}$. Journal of Chemical and Pharmaceutical Research 4(8): $3769-3777$.

19. Mulon, J. B., Destandau, É., Alain, V. and Bardez, É. 2005. How can aluminium(III) generate fluorescence? Journal of Inorganic Biochemistry 99(2005): 1749 - 1755.

20. Ulianas, A., Heng, L. Y., Hanifah, S. A. and Ling, T. L. (2012). An electrochemical DNA microbiosensor based on succinimide-modified acrylic microspheres. Sensors 12: $5445-5460$.

21. Williams, N. J., Gan, W., Reibenspies, J. H. and Hancock, R. D. (2009). Possible steric control of the relative strength of chelation enhanced fluorescence for zinc(II) compared to cadmium(II): Metal ion complexing properties of tris(2-quinolylmethyl)amine, a crystallographic, UV-visible, and fluorometric study. Inorganic Chemistry, 48: 1407 - 1415. 
22. De Silva, A. P., Gunaratne, H. N., Gunnlaugsson, T., Huxley, A. J., McCoy, C. P., Rademacher, J. T. and Rice, T. E. (1997). Signaling recognition events with fluorescent sensors and switches. Chemistry Reviews, 97(5): $1515-1566$.

23. Kaur, S., Hwang, H., Lee, J. T. and Lee, C. H. (2013). Displacement-based, chromogenic calix [4] pyrroleindicator complex for selective sensing of pyrophosphate anion. Tetrahedron Letters, 54(29): $3744-3747$.

24. Neri, T. S., Carvalho, D. C., Alves, V. N. and Coelho, N. M. (2015). Noteworthy method for direct determination of $\mathrm{Sb}^{\mathrm{III}}$ and total inorganic antimony in natural waters. Journal of the Brazilian Chemical Society, 26(5), $985-991$.

25. Zhang, Y., Hu, Y., Wilson, G. S., Moatti-Sirat, D., Poitout, V., and Reach, G. (1994). Elimination of the acetaminophen interference in an implantable glucose sensor. Analytical Chemistry, 66(7): 1183 - 1188.

26. Edwards, H. A. (1982). Ion concentration and activity in the haemolymph of Aedes aegypti larvae. Journal of Experimental Biology, 101(1): 143 - 151. 